\title{
The Influence of Quantum Learning Models based Mandailing culture and Student Learning Activity towardMathematical Communication Ability in Primary School
}

\author{
Ahmad Landong Nasution ${ }^{1}$ \\ ${ }^{1}$ Postgraduate of Basic Education, Universitas Negeri \\ Medan,Medan, 20221 North Sumatera Indonesia \\ email: ahmadlandongrangkuti@gmail.com
}

\author{
Edy Surya ${ }^{2}$ \\ ${ }^{2}$ Postgraduate of Mathematical Education, Universitas \\ Negeri Medan,, Medan, 20221 North Sumatera Indonesia \\ email: edy_surya71@gmail.com
}

\author{
Yusnadi $^{1}$ \\ ${ }^{1}$ Postgraduate of Basic Education, Universitas Negeri Medan,, \\ Medan, 20221 North Sumatera Indonesia \\ email: @gmail.com
}

\begin{abstract}
Defiancing students to communicate both orally and writing in mathematics helps extend their understanding, improve mathematical performance and reduce restlessness about mathematics. The purpose of this study was: (1) to determine differences in Mathematical Communication Ability of students who were taught with Quantum Learning Model Based on Mandailing Culture with students who were learning through Direct Learning. (2) to determine the differences in Mathematical Communication Ability Students who have High and low of student Learning Activities. (3) to determinean interaction between Quantum Learning Model Based on Mandailing Culture and Direct Learning with High or Low student Learning Activities on Students' Mathematical Communication Ability. The study population was all students the fifth grade ofSD Negeri 127 Pagur, Panyabungan Timur districts, Mandailing Natal Regency, Academic Year 2017/2018 consisted of 46 students, while the research sample consisted of 24 students. The research instrument consists of two tests and questionnaire of student learning activities. Data analysis technique used is two-way ANOVAat significant level $\alpha=0.05$. The results showed that: (1) there were differences in students 'mathematical communication skills learned through the Quantum Learning model based on Mandailing culture with students who received direct learning, this was evident from the students' average level of mathematical communication that was learned with the Quantum Learning model based on Mandailing culture. $(\bar{x}=73.15)$, while those taught with direct learning models $(\bar{x}=59.09$, $)$ with sig.0,017 values; (2) there is an effect of the activity of students given a Quantum Learning Model based on Mandailing culture with Direct learning, this can be seen from the average value of students' mathematical communication skills with high activity $(\bar{x}=47.33)$ while students with low activity $(\bar{x}=39.11)$ with sig. $0,000<0,05$; (3) there are interactions between the two models with student learning activities in influencing students' mathematical communication skills with sig. 0.045 , where the mathematical communication ability of students taught by the Quantum Learning Model based on Mandailing culture is the high group $\bar{x}==47.33$ and the low group $\bar{x}=39.11$ is greater than the students taught with expository learning ie high group $\bar{x}=49,125$, and low group $\bar{x}=39,35$. From the above statements, the application of the Quantum Learning model based on
\end{abstract}

Mandailing culture can influence students' mathematical communication skills.

Keywords:Quantum Learning Model; Mathematical Communication Ability; Mandailing Culture; Student Learning Activities

\section{INTRODUCTION}

Communication is an important part of every learning activity. But in reality many students experience difficulties in learning mathematics. Based on the research of [1], "students still experience difficulties in solving mathematical problems related to the ability to provide answers using their own language. On the other hand, intelligent students in mathematics are often less able to convey the results of their thoughts [2]

Communication skills are a very important aspect that needs to be possessed by students who want to succeed in their studies. Students who have good mathematical communication skills tend to be able to make diverse representations, making it easier for students to obtain alternative solutions to various mathematical problems ([3]). Mathematical communication skills are difficult to develop if the student learning process is passive. Teachers are expected to create teaching and learning situations that involve more student learning activities, so that students' mathematical communication skills can be trained, while students themselves should be able to motivate themselves to be active in teaching and learning activities. With this learning activity it is likely that students' mathematical communication is better and the student's learning achievement will be satisfying.

Many factors influence students who think mathematics is difficult to learn. This fits with reality, the implementation of the learning process in the classroom does not train and develop student communication skills to cause interaction between students, such as working together, expressing ideas, asking questions, and responding to other students' questions/ opinions. So there is a need for appropriate learning methods and strategies to overcome these problems. One of them is 
Quantum Learning. The advantages of Quantum Learning Model according to [4] where this learning involved students more during the learning process, in accordance to the syntax of mathematical communication skills where students can find new ideas, and write them correctly, andcommunicate them mathematically. This is in accordance to[5], the improvement of students' mathematical communication skills that gained learning by applying the Quantum Learning approach was better than the motivation of students who received direct learning. Then, [6] concluded that the Quantum Learning model can improve mathematical communication skills and the activities of VII grade students of SMP 13 Banjarmasin for topic lines and angles.

In this article, researchers adopted a Quantum learning model with a culture, especially local culture, to see the influence of models and learning activities on communication skills. Because according to [7], almost all (80\%) of 80 students did not understand the culture that existed during mathematics learning as it was known that culture is the foundation of character formation, especially focusing on teacher characteristics.

\section{QUANTUM Learning BASED ON MANDAILING CUlture}

According to the translation of the Quantum Learning book: Unleashing the Genius in You by Bobbi DePorter with Mike Hernacki, Quantum Learning is rooted in Dr. Georgi Lozanov, a Bulgarian educator who experimented with what he called "suggestology" or "suggestopedia". The principle is that suggestions can and certainly affect the outcome of the learning situation and any detail gives positive or negative suggestions ([8]).

Quantum Learning is a tips, instructions, strategy and whole learning process that can sharpen understanding and memory, and make learning a fun and useful process. Quantum Learning is also interpreted as a lively change of learning with all its nuances, which includes all links, interactions and differences that maximize learning moments and focus on dynamic relationships in a classroom-interaction environment that establishes a foundation in order to learn ([8]).

To do learning with the Quantum Learning approach, a teacher must understand the differentiation of individual students. This individual difference will automatically give rise to the fresh zone or comfort zone for students. The comfort zone in Quantum Learning terminology is known as "student learning style / modality".

Quantum Learning also relies on another concept that is "bring the world of students to the world of teachers, and bring the world of teachers to the world of students". This means that a teacher's first step in the activities of the teaching and learning process is to understand or enter the world of students, as part of learning activities. This action will provide opportunities / permission for the teacher to lead, guide and facilitate the activities of students in the teaching and learning process. This activity is carried out by linking what the teacher will teach with an event, thought, or feeling obtained from home life, social, athletic, music, art, recreation or academic students (DePorterdan and Henarcki, (2016)). Once the link is formed, students can be brought to the teacher's world, and give students an understanding of the content of learning.

Given and [8] mentioned Learning and teaching are dynamic and complex openings. The Quantum Learning system component is Culture and Cognitive.

Quantum Learning is the compilation of lively learning, with all its nuances. Quantum Learning also includes all links between, interactions and differences that maximize learning moments. Quantum Learning focuses on dynamic relationships in the classroom environment, interactions that establish the foundation and framework for learning. Quantum Learning contains the principles of an effective, efficient and progressive teaching design system and its presentation method to get amazing learning results with little time. In Quantum Learning practice "Learning relies on the main principle" bring their world to our world, and bring our world into their world ". Everything that is done within the framework of Quantum Learning is every interaction with students, every curriculum design, and every method of instruction is built on this principle. "

According to [8] the principle of Quantum Learning is learning that leads to collaboration between teachers and students so that there is a good stimulus-response. For example, before the teacher teaches the teacher should prepare in advance the media and learning methods that will be applied and before learning the material students are first given the analogy of concepts and general theory as a task to be learned later when learning. The material or task used is interdisciplinary and emphasizes authentic natural ingredients.

\section{RESEARCH METHODOLOGY}

This study was carried out on two groups: experimental and control classes. The experimental class was a class that applied the Quantum Learning model based on Mandailing Natal Culture and the control class applied direct learning. Both sample classes were given pretest and then in the experimental class and control class. The design in this study used the posttest control group shown in the following table ([9]).

TABLE I. RESEARCH DESIGN

\begin{tabular}{|c|c|c|}
\hline \multirow{2}{*}{$\begin{array}{c}\text { Learning } \\
\text { Activity } \\
\text { (B) }\end{array}$} & \multicolumn{2}{|c|}{$\begin{array}{c}\text { Learnig Model } \\
\text { (A) }\end{array}$} \\
\cline { 2 - 3 } & $\begin{array}{c}\text { QL Based Natal } \\
\text { Mandailing Natal } \\
\text { Culture } \\
A_{1}\end{array}$ & $\begin{array}{c}\text { Direct Learning } \\
A_{2}\end{array}$ \\
\hline $\begin{array}{c}\text { High } \\
B_{1}\end{array}$ & $A_{1} B_{1}$ & $A_{2} B_{2}$ \\
\hline $\begin{array}{c}\text { Low } \\
B_{2}\end{array}$ & $A_{1} B_{2}$ & $A_{2} B_{2}$ \\
\hline
\end{tabular}

A $=$ Learning Model.

$\mathrm{B}=$ Interaction of Learning Activity

$A_{1}=$ Quntum Learning Based Natal Mandailing Natal Culture 
$A_{2}=$ Direct Learning

$B_{1}=$ High Learning Activity

$B_{2}=$ Low Learning Activity

$A_{1} B_{1}=$ Student's Mathematical Communication Ability who are taught with Quantum Learning based on Mandailing Natal Culture with High Learning Activity

$A_{1} B_{2}=$ Student's Mathematical Communication Ability who are taught with Quantum Learning based on Mandailing Natal Culture with Low Learning Activity

$A_{2} B_{1}=$ Student's Mathematical Communication Ability who are taught with Direct Learning with High Learning Activity

$A_{2} B_{2}=$ Student's Mathematical Communication Ability who are taught with Direct Learning with Low Learning Activity

This study used several tests, namely the initial mathematics ability, the students' mathematical communication skills, the scale of student learning activities. To obtain data on students' mathematical communication skills, an essay-shaped test was used, and observation sheet that aims to measure the level ofstudent's and teacher's activitiesin learning. While the instrument was used in measuring student learning activities takes the form of a scale with guidelines on the form of a Likert scale.

The learning process will be assessed every meeting, then the score of the observer results is processed using the formula:

$$
p_{i}=\frac{\sum_{j=0}^{n} x_{j}}{n}
$$

Where $p_{i}$ is the value of the ith learning process, $n$ is the many aspects observed, $x_{j}$ is the observed aspect. To determine the average rating, it usedwith the following formula.

$$
R=\frac{N}{B}
$$

where $R=$ average rating, $N=$ Number of final score, $B=$ number of observation.

From the trieled results of class of VI-A student at SDN 127 Pagur, Panyabungan Timur District, Mandailing Natal Regency, the validity of the items on the students' mathematical communication skills test in the sixth grade students of SD Negeri 127 Pagur, Panyabungan Timur District, Mandailing Natal District., then the questions that will be used in this study are 3 questions, namely $1 \mathrm{~b}, 2 \mathrm{a}$, and $4 \mathrm{~b}$, while the reliability of the students' mathematical communication ability test is 1.1159 which means that the reliability of the item is very high.

To answer research questions, it is necessary to analyze and interpret research data. The analysis used is data description statistical analysis and inferential statistical analysis or two-way ANAVA analysis.

\section{RESULT AND DISCUSSIONS}

A. Result of Student's Mathematical Communication Skills The analysis carried out in this study used descriptive analysis and two-ways ANAVA that obtained the posttest of Mathematical Communication Ability in Experiment class taught with Quantum Learning Model on average by 73.15, a standard deviation of 15.68 , minimum value of 33.33 and maximum value is 100 . From the results of the students' answers, there were no students who got very less scores, less category, and enough value category, while those with good category scores were 22 people or $91.67 \%$, and those who had very good category scores 2 students or $8.33 \%$. Whereas, the value of Posttest is also given by control class consisting of 22 students through the Direct Learning Model

TABLE II. Descriptive Statistics

\begin{tabular}{|l|r|r|r|r|r|r|}
\hline & N & Minimum & Maximum & Sum & Mean & $\begin{array}{c}\text { Std. } \\
\text { Deviation }\end{array}$ \\
\hline $\begin{array}{l}\text { Postes_kon } \\
\text { Valid N } \\
\text { (listwise) }\end{array}$ & 22 & 50 & 89 & 1566 & 71,18 & 13,933 \\
\hline
\end{tabular}

By direct learning, there are 6 students who get very little value, which has a value of less category as many as 5 students or by $22.72 \%$, has enough category scores of 6 students or by $27.27 \%$, has as many good category scores 5 people or $22.72 \%$, and no one has a very good category value or $0 \%$. 2. Furthermore, the results of student answers, in the category of very less and there are less is 11 students. It is because students do not understand the concept so that the answers given do not mean anything. For good and very good categories students have reached as many as 5 students, because the explanation given by students is mathematically reasonable and clear and logically interrupted.

\section{B. Results of Student's Mathematical Communication} Abilitywith High and Low Learning Activities

The results of mathematical communication skills with high learning activities can be seen from the Minimum value, maximum, mean and standard deviation for each Quantum Learning based on Mandailing Natal Culture (Experiment) and Direct Learning (Control)

TABLE III. DESCIPTIVE STATISTICS SCORE

\begin{tabular}{|c|c|c|}
\hline Descriptive Statistics & High Activity & Low Activity \\
\hline Minimum Value & 33,33 & 55,56 \\
\hline Maximum Value & 100 & 100 \\
\hline Number of sample & 46 & 6 \\
\hline Median (Me) & 66,67 & 83,35 \\
\hline Mode (Mo) & 66,67 & 77,78 \\
\hline average & 70.37 & 81,48 \\
\hline Variance $\left(S^{2}\right)$ & 232,38 & 230,41 \\
\hline Deviation Standard $(\mathrm{S})$ & 15,24 & 15,17 \\
\hline
\end{tabular}




\section{Hypothesis Test}

The hypothesis test that will be analyzed in this article as follows:

1. $H_{0}$ : There is no difference between the Student's Mathematical Communication Ability who are taught with the Quantum Learning Model based on the Mandailing Natal Culture and students who are taught by the Direct Learning Model.

$H_{a}$ : There are difference between the Student's Mathematical Communication Ability who are taught with the Quantum Learning Model based on the Mandailing Natal Culture and students who are taught by the Direct Learning Model.

2. $H_{0}$ : There is no difference between mathematical communication skills that student whose high and low learning activities.

$H_{a}$ : There is difference between mathematical communication skills that have high learning activities and students who have low learning activities.

3. $H_{0}$ : There is no interaction between the Learning Models (Quantum Learning and Direct Learning) and student learning activities (High and Low) in influencing students' Mathematical Communication Skills.

$H_{a}$ : There is interaction between the Learning Models (Quantum Learning and Direct Learning) and student learning activities (High and Low) in influencing students' Mathematical Communication Skills.

Following are the results of calculations using SPSS 17

TABLE IV. TESTS OF BETWEEN-SubJECts EFFECTS

Dependent Variable: Score_Posttest

\begin{tabular}{|l|l|l|l|l|l|}
\hline Source & $\begin{array}{l}\text { Type III Sum of } \\
\text { Squares }\end{array}$ & Df & $\begin{array}{l}\text { Mean } \\
\text { Square }\end{array}$ & F & Sig. \\
\hline $\begin{array}{l}\text { Corrected } \\
\text { Model }\end{array}$ & $15231,702^{\mathrm{a}}$ & 3 & 5077,234 & 32,058 &, 000 \\
Intercept & 182440,037 & 1 & 182440,037 & 1151,942 &, 000 \\
Model & 986,957 & 1 & 986,957 & 6,232 &, 017 \\
Activity & 11040,888 & 1 & 11040,888 & 69,713 &, 000 \\
$\begin{array}{l}\text { Model } \\
\text { Activity }\end{array}$ & 674,303 & 1 & 674,303 & 4,258 &, 045 \\
Error & 6651,793 & 42 & 158,376 & & \\
Total & 213221,457 & 46 & & & \\
$\begin{array}{l}\text { Corrected } \\
\text { Total }\end{array}$ & 21883,496 & 45 & & & \\
\hline
\end{tabular}

a. R Squared =,696 (Adjusted R Squared $=, 674$ )

\section{a) First Hypothesis}

Testing of the first hypothesis is that there are differences in Mathematical Communication Ability using the Quantum Learning Model Based on Mandailing Natal Culture and Direct Learning Models.

Based on two-ways ANAVA obtained significant numbers on the variablesmodel obtained sig. $0.017<0.05$ so initial hypothesis (Ho) is rejects, otherwise accepts alternative hypothesis (Ha). Thus it can be concluded that there are significant differences between Quantum Learning Models based on Mandailing Natal Culture and Direct Learning Models on student's Mathematical Communication Ability. This can be seen from the average value obtained by student with Quantum Learning based on Mandailing Natal Culture model ( $\left.\mathrm{x}^{-}=73.15\right)$ while the Student's Mathematical Communication Ability by the Direct Learning Model $(\bar{x}=$ 59.09).

\section{b) Second Hypothesis}

Testing of the second hypothesis is that there are differences in mathematical communication skills that have high learning activity with students who have low learning activity. Based on two-ways ANAVA obtained significant numbers on the variable activity obtained $0.000<0.05$ so that the initial hypothesis(Ho)is rejected and otherwise accepts alternative hypothesis (Ha). Thus it can be concluded that it are significant differences between Mathematical Communication ability that have high learning activity with students who have low learning activity. This can be seen from the average activity obtained by theQuantum Learning Mandailing Natal Culture model ( $\bar{x}=52.77)$ while the learning activities using the Direct learning model $(\bar{x}=25.75)$.

\section{c) Third Hypothesis}

Testing of the third hypothesis is that there is an interaction between the Learning Models (Quantum Learning and Direct Learning) and student learning activities (High and Low) in influencing students' Mathematical Communication Skills. Based on two-ways ANAVA obtained significant values of Model * Activity obtained $0.045<0.05$ so testing of the initial hypothesis (Ho)is rejected and otherwise Ha is accepted. Thus it can be concluded that there is an interaction between Quantum Learning models based on Mandailing Natal Culture and Mathematical Communication Ability to Learning Activity. The results of the interaction between learning models and learning activities in influencing students' mathematical communication skills can be presented in graphical form in Figure 1 


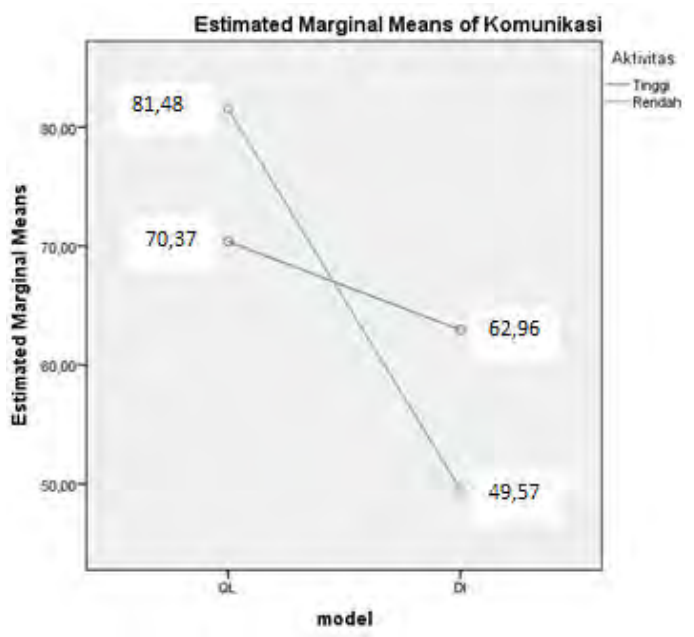

Fig 1. Graph of Interaction of Learning Models with Student's Learning Activities

Based on the graph in Figure 1 it showed that the group of students who have high learning activity taught using the Quantum Learning Model Based on Mandailing Natal Culture obtained an average score of Students' Mathematical Communication Ability of 70.37. While the group of student who have high learning activity taught by the Direct Learning Model obtained an average score of Student Mathematical Communication Ability of 62.96. This shows that the interaction of students who have high learning activity using the Quantum Learning Model based on Mandailing Natal Culture is much better thanthe high learning activityby Direct Learning Model.

So it happens to students who have low learning activities are taught by the Quantum Learning Model based on Mandailing Natal Culture, obtaining an average score of Mathematical Communication Ability of 81.48. While thestudents who have low learning activity taught using the Direct Learning Model obtained an average score of Mathematical Communication Ability of 49.57. This shows that the interaction of students who have low learning activity using Quantum Learning Model Based on Mandailing Natal Culture is better than students who done by the Direct Learning Model. It can be seen from the graph of low learning activity influeting Mathematical Communication Ability.

Based on the acquisition, it can be concluded that there is an interaction between the Quantum Learning Model based on Mandailing Natal Culture and Student Learning Activities on Mathematical Communication Ability, on high and low learning activities. The picture above can also show that the Quantum Learning Model Based Mandailing Natal interacts and student learning activities is much better for Mathematical Communication Ability.

For more information about the interaction between learning models and student activities, the students of each group analyzed the mean differences in Mathematical Communication Ability. This follow-up test used Post Hoc Test with the Tukey test whose results are presented in Table 5 .
TABLE V. Pots Hoc Test with Tukey Test

Multiple Comparisons

Dependent Variable: Skor_Postes

Scheffe

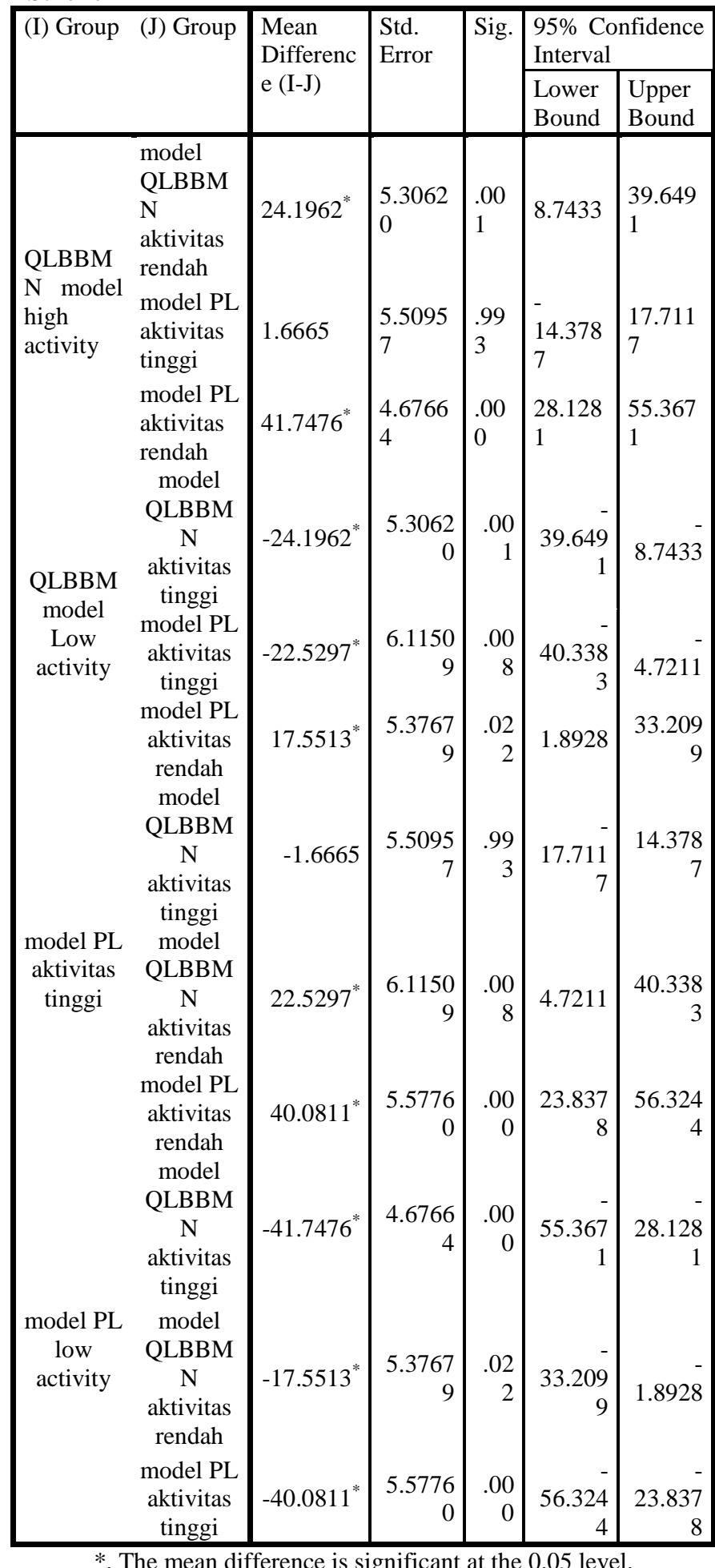

- If significant value sig. $<0,05$ then there are differences in students' mathematical communication skills between the two groups. 
- If significant value sig.> 0,05 then there is no differences in students' mathematical communication skills between the two groups.

The following will explain the analysis in table 2 of the results of the Post Hoc Test with the Tukey Test:

1. The results of the Tukey Test show that there is a significant difference in students' mathematical communication skills between learning groups and Quantum learning based on Mandailing Natal culture which has high activity with groups that are taught using Quantum Learning based on Mandailing Natal culture which has low learning activity (mean diff $=24,196$; sig $0.01<0.05$ )

2. The results of the Tukey Test calculation showed that there are significant differences in students' mathematical communication skills between groups that are taught using Quantum Learning based on Mandailing Natal culture which has high activity with groups that are taught by direct learning that have low activity (mean diff $=$ 41.74; sig. $000<0.05$ )

3. Tukey Test calculation results show that there are significant differences in students' mathematical communication skills between groups that are taught using Quantum Learning based on Mandailing Natal culture which has low activity with groups that are taught by direct learning that have low activity (mean diff $=$ 17.55 ; sig. $0,22<0.05$ )

4. The results of the Tukey Test calculation show that there are significant differences in students' mathematical communication skills between groups taught by direct learning that have high activity with groups that are taught by direct learning that have low activity (mean diff $=40.08$; sig. $0.00<0.05$ )

From the results of the above analysis, it can beconcluded that there are significant differences in students' mathematical communication skills between groups that are taught using the Quantum Learning Model based on Mandailing Natal Culture with Direct Learning which has high and low activity.

\section{CONCLUSION}

Based on the results and discussions described earlier, some conclusions can be drawn by referring to the formulation of the research problem. The conclusions are as follows:

1. There is distinction in students' mathematical communication skills. This is proven through calculations that show significant distinction in learning outcomes between students taught with the Quantum Learning model based on Mandailing Natal culture and direct learning

2. There are distinction in student's learning activity towards Mathematical Communication Ability of fifth grade of SDN 127 Pagur, Panyabungan Timur District, Mandailing Natal Regency, and Academic year 2017/2018.

3. There is an interaction between the two models with student learning activity in influencing students' mathematical communication skills. Learning activities play a role in students with high and low learning activities taught by the Quantum Learning model based on Mandailing Natal culture compared to those taught with direct learning.

\section{REFERENCES}

[1] M.A.Jatmiko, G. Dwirahayu, F. Diwidian, "The Effect of TAPPS Method to Students Mathematical Communication Skill", International Proceeding the $5^{\text {th }}$ International Prost graduate Colloqium On Research In Education, November 4-6 2016 pp 32-38

[2] Armiati. "Komunikasi Matematis dan Kecerdasan Emosional". Seminar Nasional Matematika dan Pendidikan Matematika Jurusan Pendidikan Matematika FMIPA UNY 5 Desember 2009 hal 270-280

[3] D. Suhaedi. "Peningkatan Kemampuan Komunikasi Matematis Siswa SMP Melalui Pendekatan Pendidikan Matematika Realistik", Seminar Nasional Matematika dan Pendidikan Matematika, Jurusan Pendidikan Matematika FMIPA UNY, 10 November 2012

[4] A. Shoimin. "68 Model Pembelajaran INOVATIF dalam Kurikulum 2013". Yogyakarta: AR-RUZZ MEDIA

[5] M. Darkasyi, R. Johar, A. Ahmad, "Peningkatan Kemampuan Komunikasi Matematis dan Motivasi Siswa dengan Pembelajaran Pendekatan Quantum Learning pada Siswa SMP Negeri 5 Lhokseumawe", Jurnal Didaktik Matematika, 1 ( 1) 2014 hal. 21-34

[6] E. Kusumawati and Manopo. "Meningkatkan Kemampuan Komunikasi Matematis Siswa Menggunakan Model Pembelajaran Quantum". EDUMAT Jurnal Pendidikan Matematika, Vol. 4, No. 2, 2016 hal 118-125

[7] A. Supriadi dan Tiurlina, "Mengintegrasikan Pembelajaran Matematika Berbasis Budaya Banten pada Pendirian SD Laboratorium UPI Kampus Serang", Mimbar Sekolah Dasar, Vol 3(1) 2016 Hal 1-18

[8] B.DePorter dan Hernacki, Quantum Learning, Bandung: KAIFA. 2016

[9] Sugiyono. Metode Penelitian Pendidikan Pendekatan Kuantitatif dan Kualitatif, $R \& D$. Bandung Alfabeta 2014 